А.А. Зимирова, М.В. Поспелов, А.В. Иванова, Л.Н. Дмитриева, Е.А. Чумачкова, И. Г. Карнаухов, С. А. Щербакова, В. В. Кутырев

\title{
Анализ динамики эпидемического процесса COVID-19 в мире за неделю с 04.12.2021 г. по 10.12.2021 г.
}

ФКУЗ Российский научно-исследовательский противочумный институт «Микроб» Роспотребнадзора, Саратов, Российская Федерация

В обзоре представлен анализ эпидемиологической ситуации в странах мира по COVID-19, за неделю с 04.12.2021 г. по 10.12.2021 г.

Анализ проведен на основании данных следующих ресурсов:

1. www.worldometers.info/coronavirus/

2. tass.ru/pandemiya-covid-19

3. www.skyscanner.ru/travel-restrictions

4. reopen.europa.eu/en/map/LVA/7001

5. intelyse.com/coronavirus-travel-restrictions/

6.gisanddata.maps.arcgis.com/apps/dashboards/bda7594740fd40299423467b4 $8 \mathrm{e} 9 \mathrm{ecf6}$ 
Всего в мире зарегистрирован 268500781 случай заболевания (35097 на 1 млн. населения); прирост за неделю составил 4312210 случаев (563,7 на 1 млн. населения) - 1,6\%. Всего в мире зарегистрировано 5288465 летальных исходов (691,3 на 1 млн. населения); прирост за неделю составил 52635 случаев (6,9 на 1 млн. населения) $-1 \%$.

За неделю с 4 по 10 декабря 2021 г. показатель прироста новых случаев в сравнении с предыдущей неделей (с 27 ноября по 3 декабря 2021 г.) остался на том же уровне - 1,6\% (рис. 1; таб.1). Недельный прирост числа летальных исходов за анализируемую неделю также не изменился - $1 \%$.

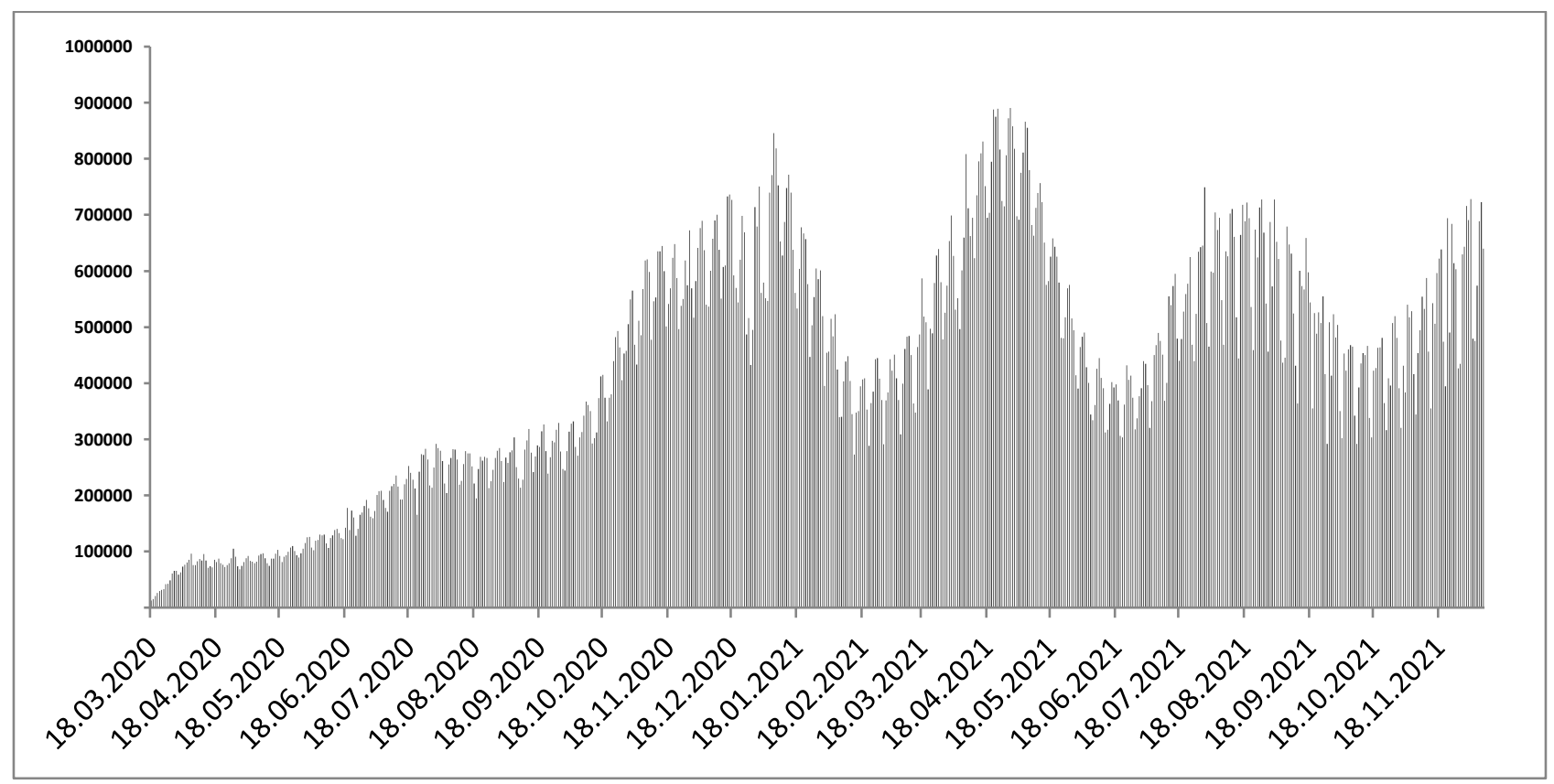

Рисунок 1 - Ежедневный прирост подтвержденных случаев в мире 
Таблица 1 - Еженедельный прирост случаев за последние полгода

\begin{tabular}{|c|c|c|c|c|c|}
\hline Неделя & $\begin{array}{c}\text { Недель- } \\
\text { ный при- } \\
\text { рост } \\
\text { (случаев) }\end{array}$ & $\begin{array}{c}\text { Недель- } \\
\text { ный при- } \\
\text { рост (\%) }\end{array}$ & Неделя & $\begin{array}{c}\text { Недель- } \\
\text { ный при- } \\
\text { рост } \\
\text { (случаев) }\end{array}$ & $\begin{array}{c}\text { Недель- } \\
\text { ный при- } \\
\text { рост (\%) }\end{array}$ \\
\hline $12-18$ июня & 2587203 & 1,5 & $11-17$ сентября & 3881581 & 1,7 \\
\hline $19-25$ июня & 2576278 & 1,5 & $18-24$ сентября & 3544821 & 1,6 \\
\hline $\begin{array}{c}26 \text { июня - } \\
\text { июля }\end{array}$ & 2650167 & 1,5 & $\begin{array}{c}25 \text { сентября - } \\
\text { октября }\end{array}$ & 3179984 & 1,4 \\
\hline $3-9$ июля & 2927889 & 1,6 & $2-8$ октября & 2991475 & 1,3 \\
\hline $10-16$ июля & 3363018 & 1,8 & $9-15$ октября & 2829038 & 1,2 \\
\hline $17-23$ июля & 3656571 & 1,9 & $16-22$ октября & 2885362 & 1,2 \\
\hline $24-30$ июля & 3978967 & 2,1 & $23-29$ октября & 3022350 & 1,2 \\
\hline $\begin{array}{c}31 \text { июля -6 ав- } \\
\text { густа }\end{array}$ & 4295399 & 2,2 & $\begin{array}{c}30 \text { октября -5 } \\
\text { ноября }\end{array}$ & 3064395 & 1,2 \\
\hline $7-13$ августа & 4386968 & 2,3 & $6-12$ ноября & 3322096 & 1,3 \\
\hline $14-20$ августа & 4416659 & 2,2 & $13-19$ ноября & 3665348 & 1,5 \\
\hline $21-27$ августа & 4617376 & 2,2 & $20-26$ ноября & 4475143 & 1,8 \\
\hline 28 августа - 3 & 4457642 & 2,1 & 27 ноября - 3 де- & 4144135 & 1,6 \\
\hline сентября & 4108660 & 1,9 & $4-10$ декабря & 4312210 & 1,6 \\
\hline $4-10$ сентября & 41089 &
\end{tabular}




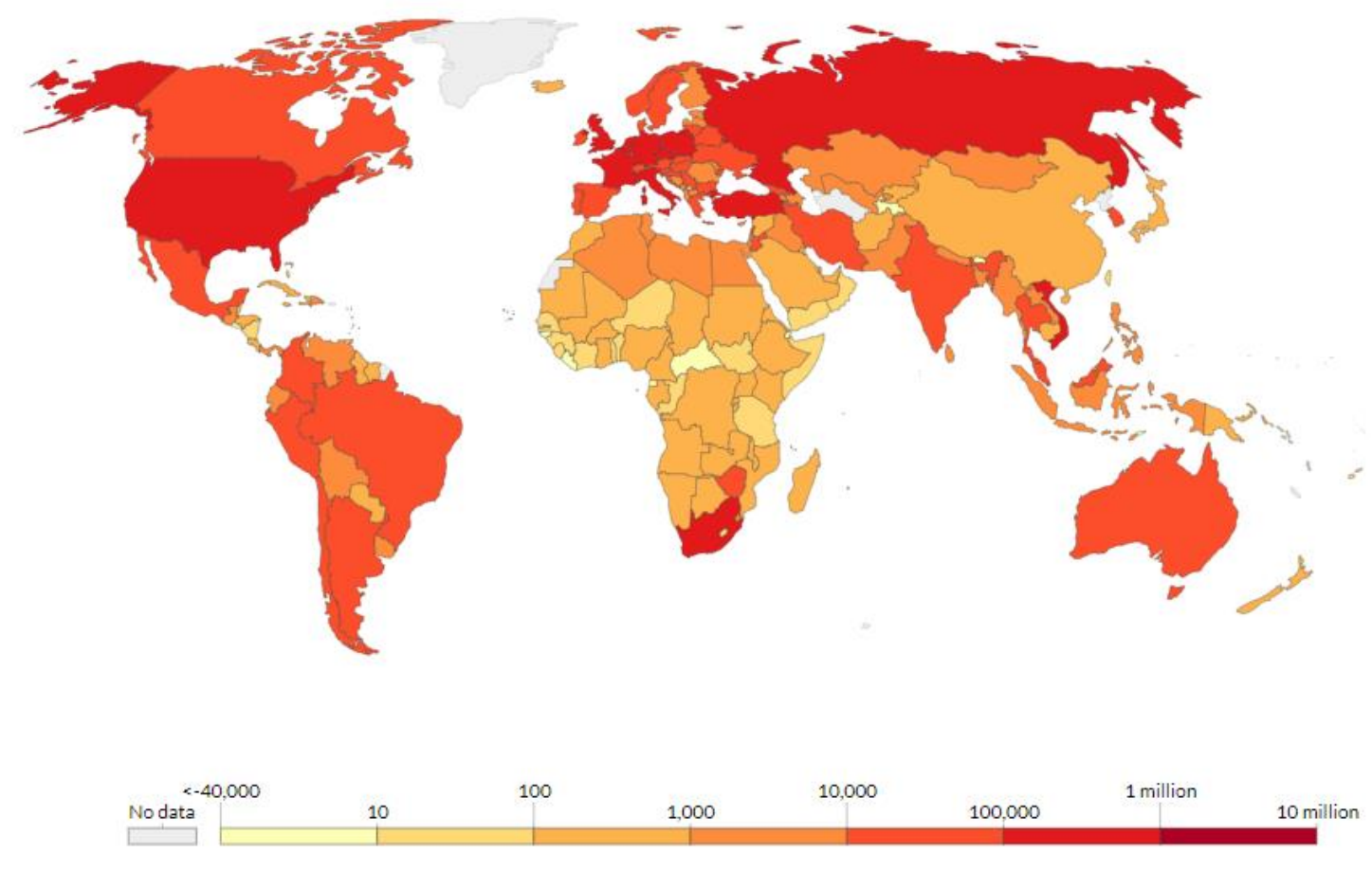

Рисунок 2 - Количество зарегистрированных случаев с 04.12.2021 г. по 10.12.2021 г.

За последнюю неделю в мире каждый день число новых случаев увеличивалось на 500 - 700 тысяч. В общей структуре заболеваемости за неделю с 4 по 10 декабря 2021 г. наибольшая доля новых случаев приходится на Европейский регион (64,3\%, показатель снизился на 3,9\%). Доля случаев в Американском регионе за неделю возросла на 2,5\% и составила 23\%. Доля ЗападноТихоокеанского региона снизилась на $0,1 \%$ в сравнении с предыдущей неделей - 4,9\%. Доля Африканского региона возросла на $1,9 \%$ в сравнении с предыдущей неделей и составила 3,2\%. За анализируемый период доля ЮгоВосточной Азии уменьшилась на $0,3 \%$ и составила 2,5\%. Наименьший удельный вес новых случаев заболевания приходится на страны ВосточноСредиземноморского региона - $2,2 \%$, доля увеличилась на $0,1 \%$ по сравнению с предыдущей неделей. 


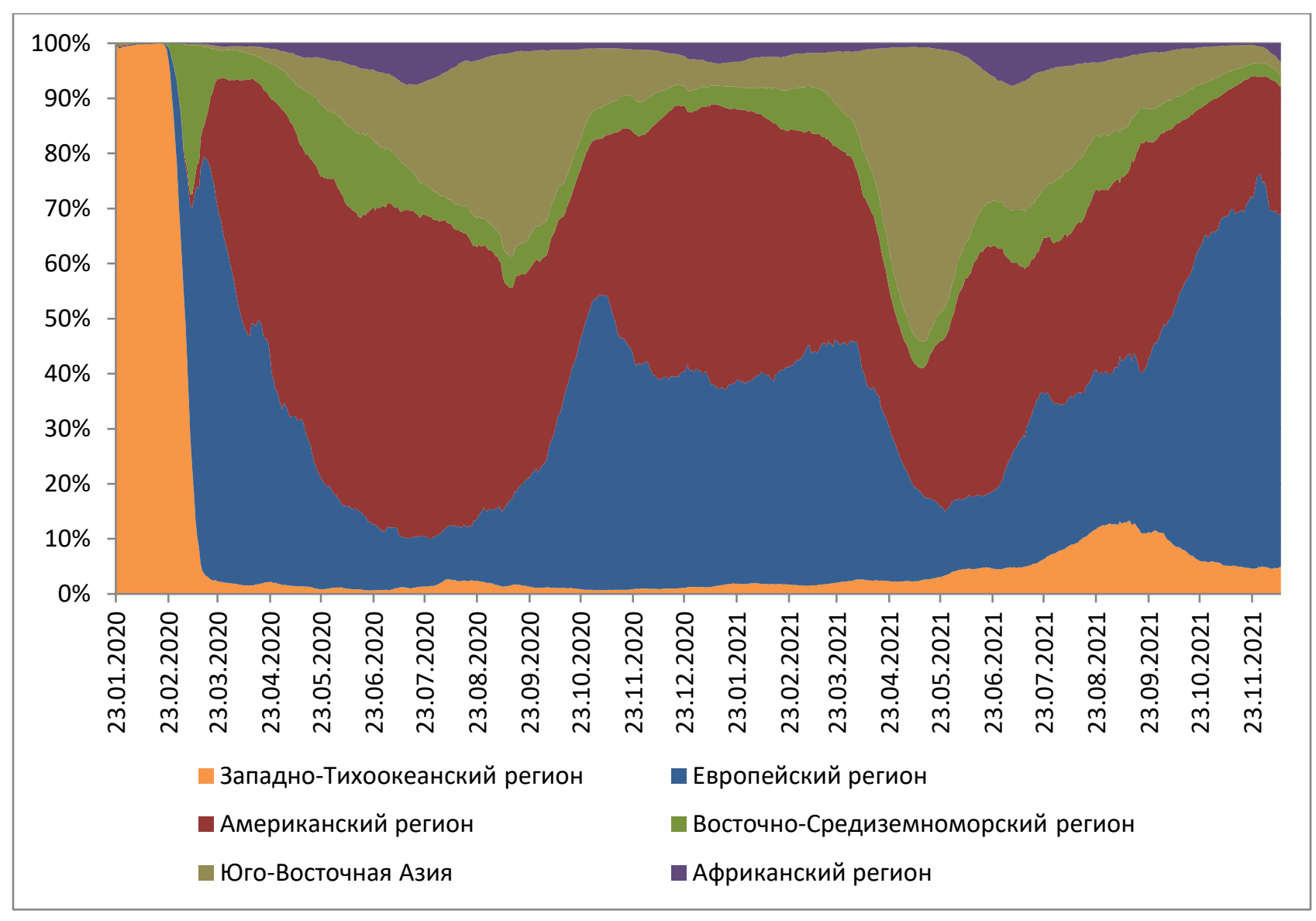

Рисунок 3 - Доля регионов мира в ежедневном приросте случаев заболевания 
Таблица 2 - Средняя доля региона от ежедневного прироста в мире

\begin{tabular}{|c|c|c|c|c|c|c|c|c|c|c|}
\hline Регионы ВОЗ & $\begin{array}{c}2-8 \\
\text { ок- } \\
\text { тября }\end{array}$ & $\begin{array}{c}9-15 \\
\text { ок- } \\
\text { тября }\end{array}$ & $\begin{array}{c}16- \\
22 \\
\text { ок- } \\
\text { тября }\end{array}$ & $\begin{array}{c}23- \\
29 \\
\text { ок- } \\
\text { тября }\end{array}$ & $\begin{array}{c}\text { оября } \\
\text { тя } \\
\text { нояб- } \\
\text { ря }\end{array}$ & $\begin{array}{c}6-12 \\
\text { ноя- } \\
\text { ря }\end{array}$ & $\begin{array}{c}13- \\
19 \\
\text { нояб- } \\
\text { ря }\end{array}$ & $\begin{array}{c}20- \\
26 \\
\text { нояб- } \\
\text { ря }\end{array}$ & $\begin{array}{c}27 \\
\text { нояб- } \\
\text { ря-3 } \\
\text { де- } \\
\text { кабря }\end{array}$ & $\begin{array}{c}\mathbf{4 - 1 0} \\
\text { де- } \\
\text { кабря }\end{array}$ \\
\hline $\begin{array}{c}\text { Западно- } \\
\text { Тихоокеан- } \\
\text { ский регион }\end{array}$ & 9,3 & 8,2 & 6,6 & 5,9 & 5,8 & 5,2 & 5 & 4,8 & 5 & 4,9 \\
\hline $\begin{array}{c}\text { Европейский } \\
\text { регион }\end{array}$ & 42,2 & 48,7 & 55,4 & 59,4 & 62,6 & 65,2 & 64,9 & 69,7 & 68,2 & 64,3 \\
\hline $\begin{array}{c}\text { Американский } \\
\text { регион }\end{array}$ & 32,7 & 28,9 & 25,5 & 23,7 & 21,8 & 21,7 & 23,2 & 19,4 & 20,5 & 23 \\
\hline $\begin{array}{c}\text { Восточно- } \\
\text { Средиземно- } \\
\text { морский реги- } \\
\text { он }\end{array}$ & 5,4 & 4,9 & 4,6 & 3,9 & 3,7 & 3,3 & 2,6 & 2,4 & 2,3 & 2,2 \\
\hline $\begin{array}{c}\text { Юго- } \\
\text { Восточная } \\
\text { Азия }\end{array}$ & 9,2 & 8,4 & 7,1 & 6,4 & 5,6 & 4,7 & 4 & 3,3 & 2,8 & 2,5 \\
\hline $\begin{array}{c}\text { Африканский } \\
\text { регион }\end{array}$ & 1,2 & 0,9 & 0,8 & 0,7 & 0,5 & 0,6 & 0,3 & 0,4 & 1,2 & 3,1 \\
\hline
\end{tabular}




\section{Американский регион}

В регионе на анализируемой неделе отмечен рост числа новых случаев заболевания на 13,2\% в сравнении с предыдущей неделей (рис. 4).

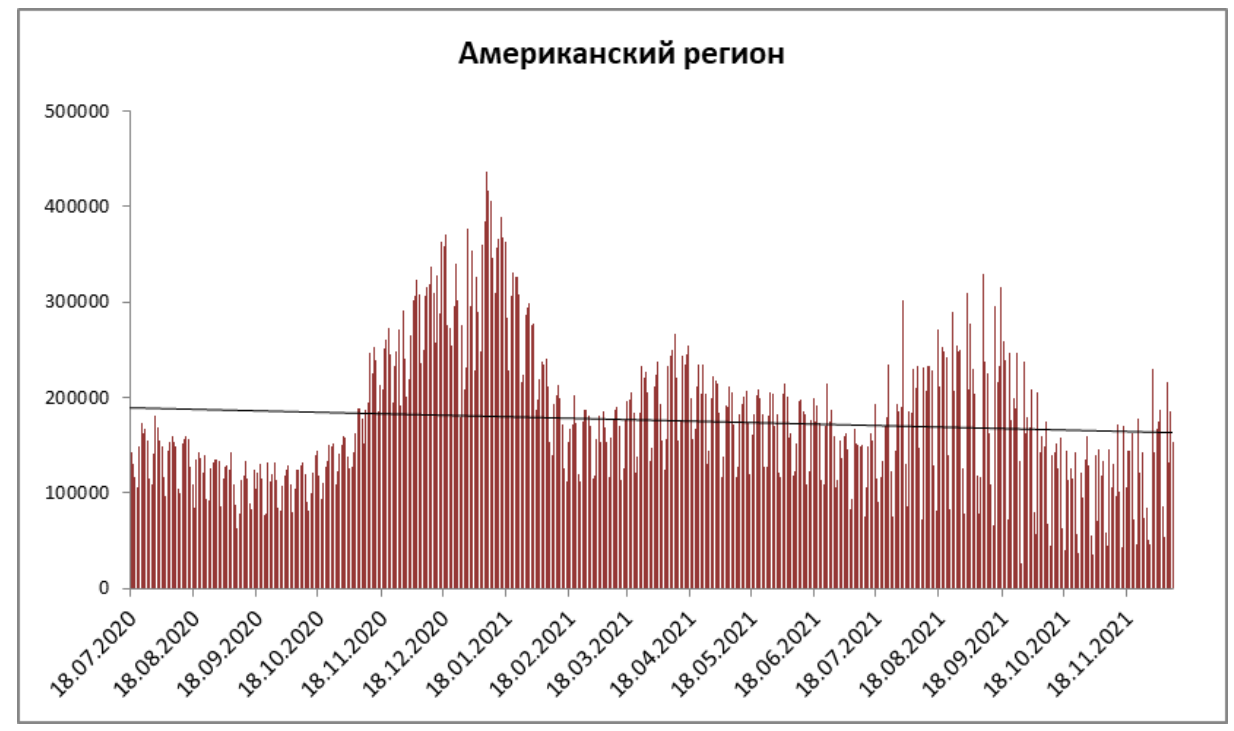

Рисунок 4 - Динамика ежедневного прироста новых случаев в Американском регионе

Количество стран региона, в которых зафиксирован рост числа новых случаев за неделю составило 13; наибольший по сравнению с предыдущей неделей - в Гондурасе и Боливии (таб. 3).

Таблица 3 - Страны с максимальным увеличением количества случаев, зарегистрированных за неделю (при сравнении недели с 27 ноября по 3 декабря и недели с 4 по 10 декабря)

\begin{tabular}{|c|c|c|c|c|c|}
\hline \multirow{3}{*}{ Страна } & \multicolumn{4}{|c|}{ Зарегистрировано } & \multirow{3}{*}{ 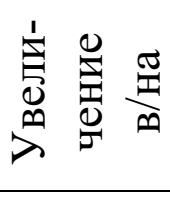 } \\
\hline & \multicolumn{2}{|c|}{ с 27 ноября по 3 декабря } & \multicolumn{2}{|c|}{ с 4 по 10 декабря } & \\
\hline & абс. число & на 1 млн & абс. число & на 1 млн & \\
\hline Гондурас & 334 & 36,5 & 501 & 55 & $50 \%$ \\
\hline Боливия & 6006 & 523,6 & 8130 & 709 & $35,4 \%$ \\
\hline
\end{tabular}


На анализируемой неделе среди стран региона по числу еженедельно выявляемых случаев доминируют Бразилия и США. Удельный вес новых случаев в общей заболеваемости в Американском регионе в этих двух странах на неделе составил $87,6 \%$ (рис. 5 ).

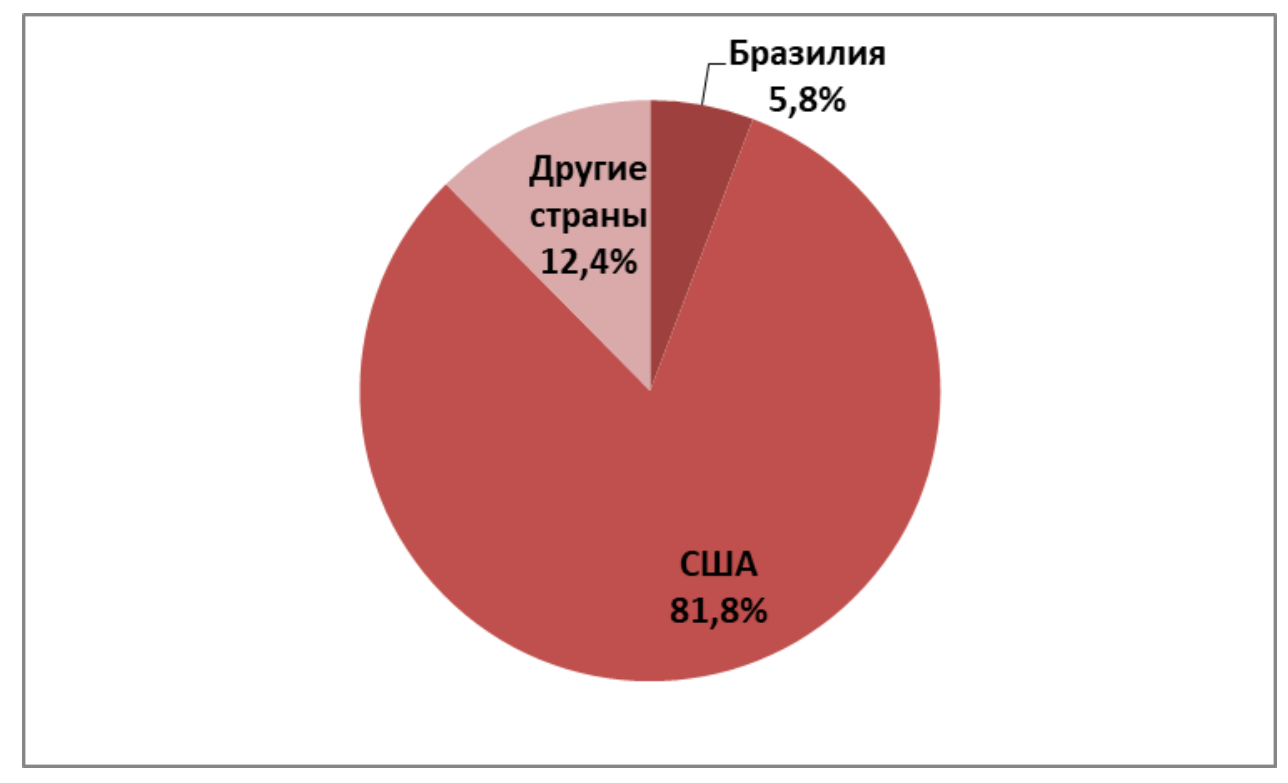

Рисунок 5 - Доля Бразилии, США и других стран в количестве случаев, зарегистрированных за отчетную неделю

Наибольшее число заболевших в регионе на 1 млн населения за последнюю неделю зарегистрировано в Тринидаде и Тобаго (3989), на Барбадосе (3268) и в США (2510). Наибольшее число летальных исходов на 1 млн населения за последнюю неделю зарегистрировано в Тринидаде и Тобаго (99), на Багамских Островах (51) и Барбадосе (45).

В настоящее время наблюдается неблагоприятная эпидситуация с COVID19 в Тринидаде и Тобаго (рис. 6). Последние несколько недель в стране наблюдается значительный рост заболеваемости. Власти Тринидада и Тобаго запретили поездки из 8 африканских стран после появления омикрон-штамма. Большинство путешественников, которые побывали в Ботсване, Эсватини, Ле- 
сото, Малави, Мозамбике, Намибии, Южной Африке и Зимбабве за 14 дней до поездки в Тринидад и Тобаго, не будут допущены к въезду.

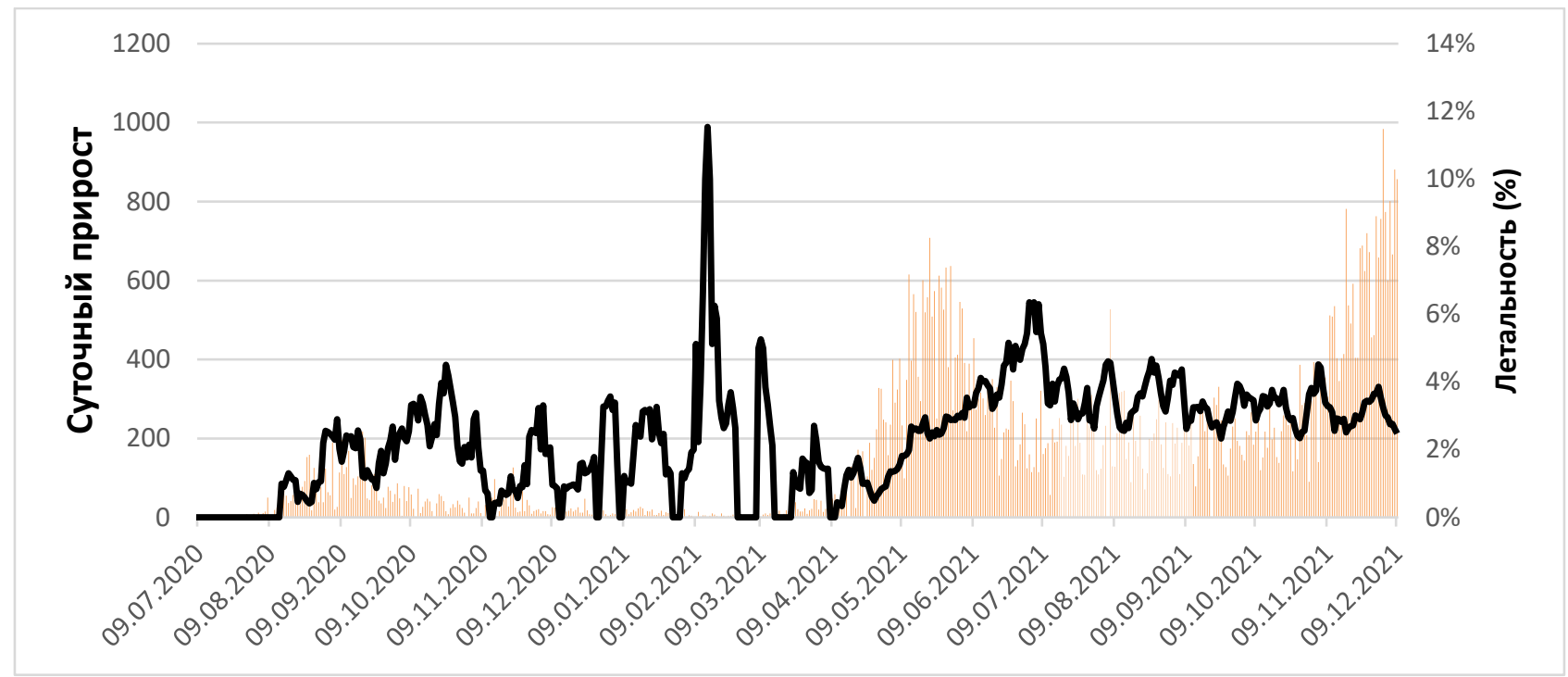

Рисунок 6 - Динамика ежесуточного прироста новых случаев заболевания и летальности в Тринидаде и Тобаго (как отношения средних показателей прироста смертей и случаев за 7-дневный период)

В США в настоящее время наблюдается рост заболеваемости COVID-19 (рис. 7). В США число полностью вакцинированных граждан достигло 200 млн, однако количество случаев заражения и летальных исходов продолжает расти по всей стране, даже в Новой Англии, которая является самым привитым регионом страны. Число ежедневно регистрируемых случаев заражения увеличилось с 95 тысяч на конец ноября до почти 119 тысяч на текущей неделе, а количество госпитализаций выросло на 25\% с прошлого месяца. Количество смертей от COVID-19 в сутки приближается к отметке в 1600, что близко к октябрьским показателям. Омикрон-штамм в настоящее время распространен примерно в трети штатов США, однако большинство новых случаев заражения в стране до сих пор приходится на дельта-вариант. 


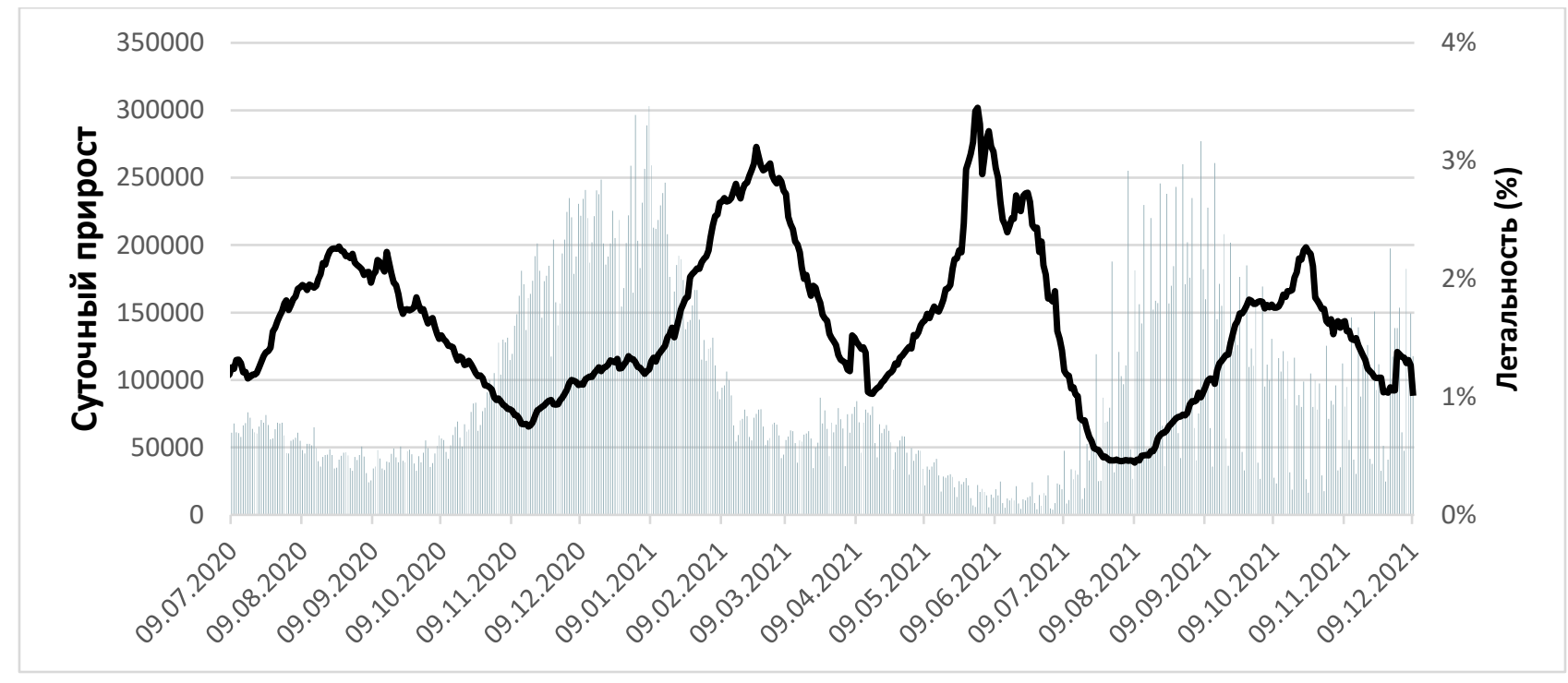

Рисунок 7 - Динамика ежесуточного прироста новых случаев в США (как отношения средних показателей прироста смертей и случаев за 7-дневный период)

\section{Европейский регион}

В Европейском регионе на анализируемой неделе отмечено снижение числа новых случаев заражения на $1,4 \%$ в сравнении с предыдущей неделей (рис. 8).

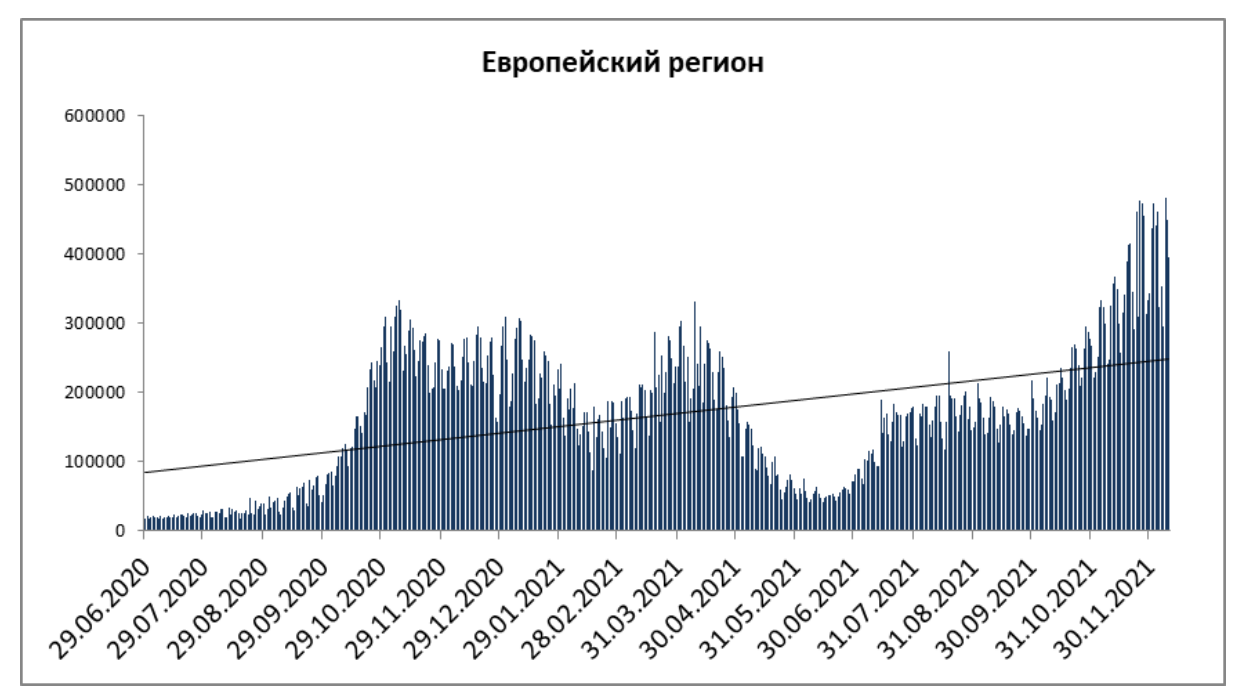

Рисунок 8 - Динамика ежедневного прироста новых случаев в Европейском регионе 
Рост заболеваемости за неделю отмечен в 21 из 56 стран региона, наибольший - в Андорре, Норвегии и Франции (таб. 4).

Таблица 4 - Страны с максимальным увеличением количества случаев, зарегистрированных за неделю (при сравнении недели с 27 ноября по 3 декабря и недели с 4 по 10 декабря)

\begin{tabular}{|c|c|c|c|c|c|}
\hline \multirow{3}{*}{ Страна } & \multicolumn{4}{|c|}{ Зарегистрировано } & \multirow{3}{*}{ 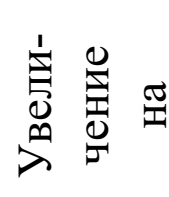 } \\
\hline & \multicolumn{2}{|c|}{ с 27 ноября по 3 декабря } & \multicolumn{2}{|c|}{ с 4 по 10 декабря } & \\
\hline & абс. число & на 1 млн & абс. число & на 1 млн & \\
\hline Андорра & 1092 & 14335 & 1614 & 21188 & $47,8 \%$ \\
\hline Норвегия & 21396 & 3854,6 & 29605 & 5334 & $38,4 \%$ \\
\hline Франция & 257834 & 3744,3 & 332421 & 4828 & $28,9 \%$ \\
\hline
\end{tabular}

Наибольшее число инфицированных на 1 млн населения в регионе за неделю зафиксировано в Андорре (21188), Словакии (13326) и Лихтенштейне (11309). Наибольшее число летальных исходов на 1 млн населения за последнюю неделю отмечено в Венгрии (136), Грузии (105) и Словакии (105).

Неблагоприятная эпидситуация с COVID-19 в настоящее время регистрируется в Норвегии (рис. 10). В связи со значительным ростом заболеваемости в Норвегии с 9 декабря ввели ряд ограничений. Так, во всех местах, где невозможно соблюдать социальную дистанцию, вводится масочным режим. Это коснется магазинов, общественного транспорта и ресторанов. Число гостей на Рождество не должно превышать 20 человек при обязательном соблюдении социальной дистанции в один метр. В другие дни число гостей не должно превышать 10 человек. Максимум 20 человек смогут встретиться на частных собраниях в общественных местах или арендованных помещениях. Кроме того, в полночь прекращается продажа алкоголя. 


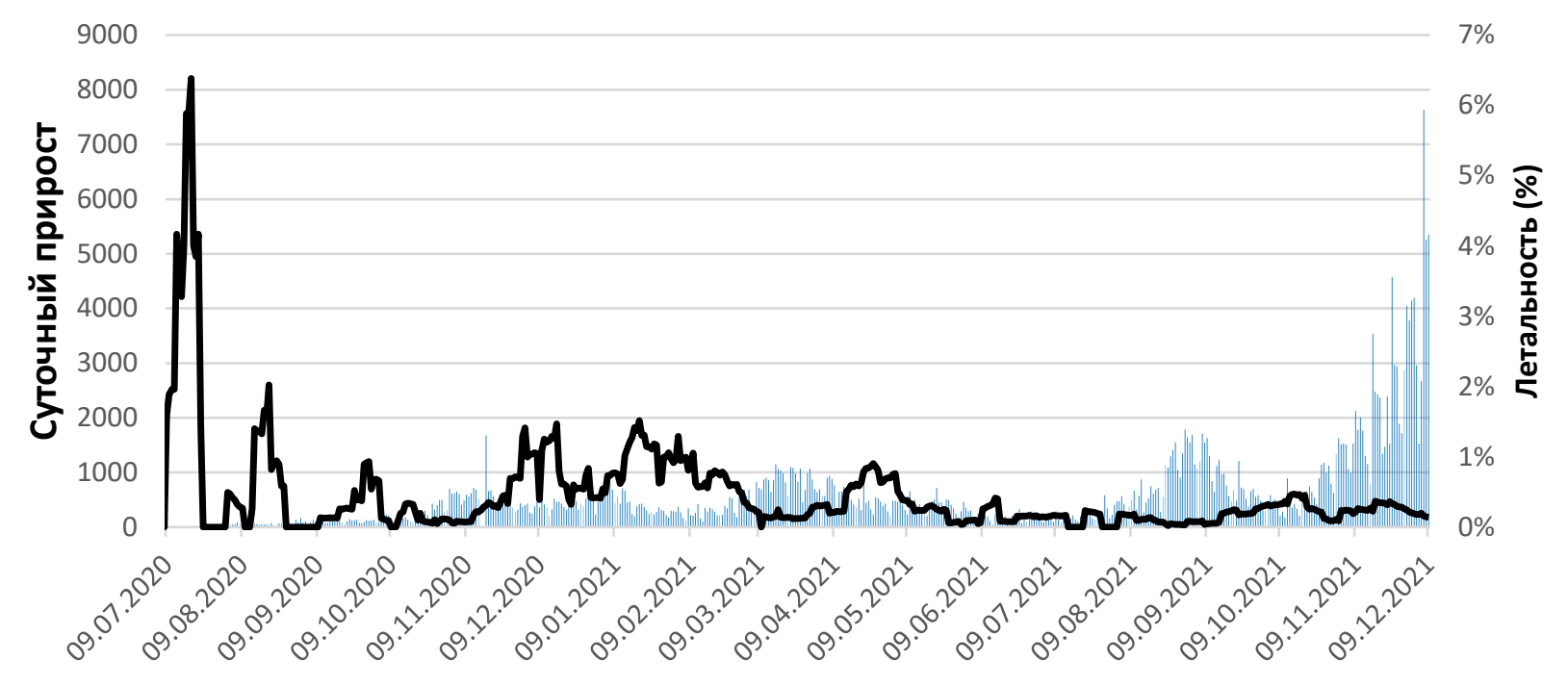

Рисунок 9 - Динамика ежесуточного прироста новых случаев заболевания и летальности в Норвегии (как отношения средних показателей прироста смертей и случаев за 7-дневный период)

В настоящее время рост заболеваемости COVID-19 наблюдается во Франции (рис. 9). Во Франции 8 декабря выявили свыше 61,3 тыс. случаев заражения COVID-19, что является самым высоким суточным приростом с 2 ноября 2020 года. Показатель заболеваемости в стране возрос до 448 случаев на 100 тыс. человек. В связи с этим, в стране с 10 декабря на четыре недели запретили дискотеки. Работодатели должны при возможности позволить сотрудникам 2-3 дня в неделю работать дистанционно.

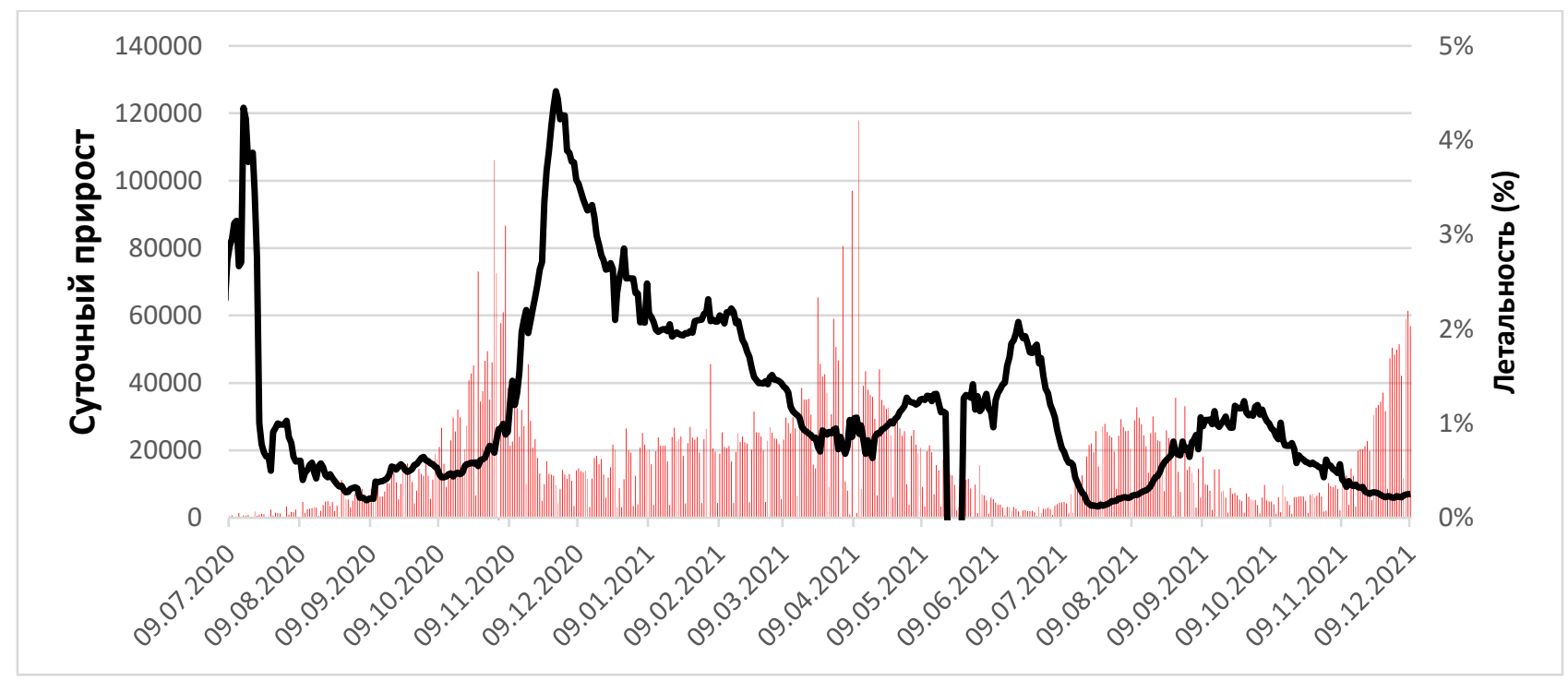


Рисунок 10 - Динамика ежесуточного прироста новых случаев заболевания и летальности во Франции (как отношения средних показателей прироста смертей и случаев за 7-дневный период)

Доля выявленных случаев в странах СНГ от всех зарегистрированных в Европейском регионе составила $11,8 \%$ - снижение на $0,8 \%$ по сравнению с прошлой неделей (рис. 11).

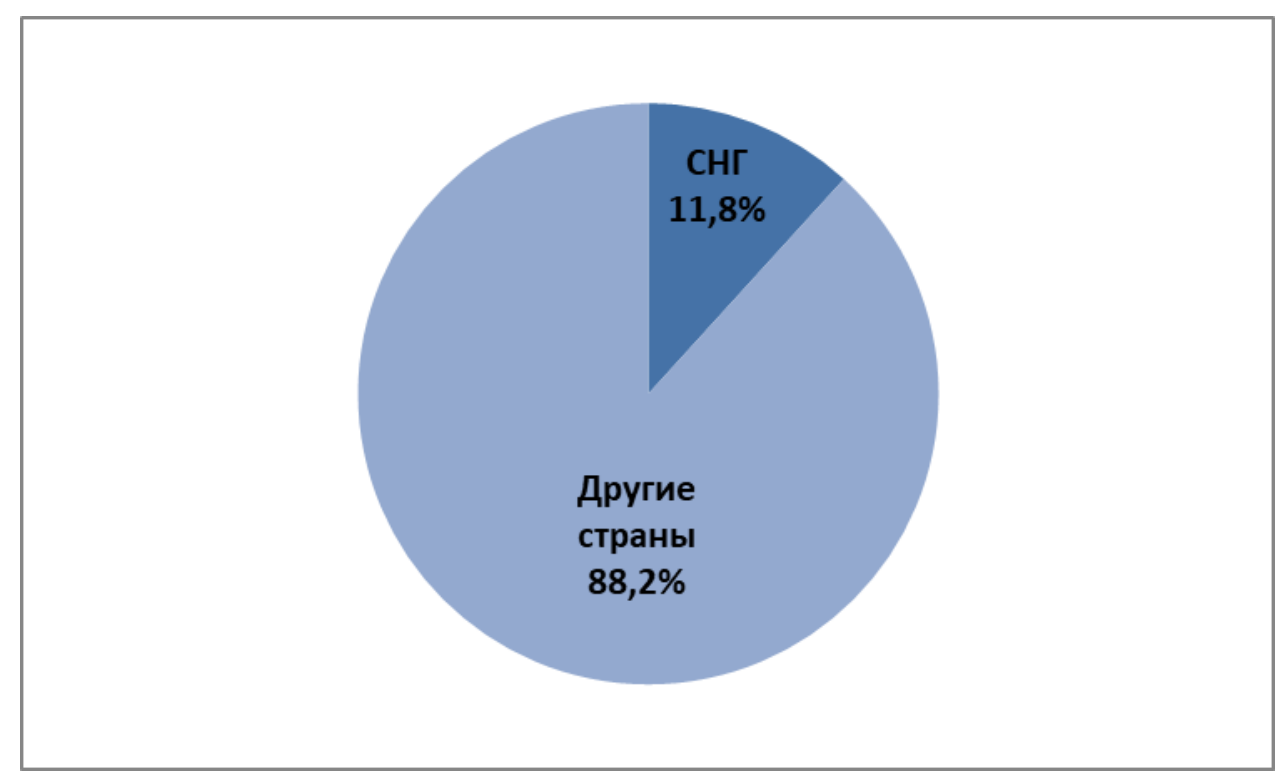

Рисунок 11 - Доля стран СНГ и других стран в количестве случаев, зарегистрированных за отчетную неделю в Европейском регионе

\section{Западно-Тихоокеанский регион}

На анализируемой неделе в Западно-Тихоокеанском регионе отмечен рост числа решистрируемых случаев на $4,3 \%$ в сравнении с прошлой неделей (рис. 12). 


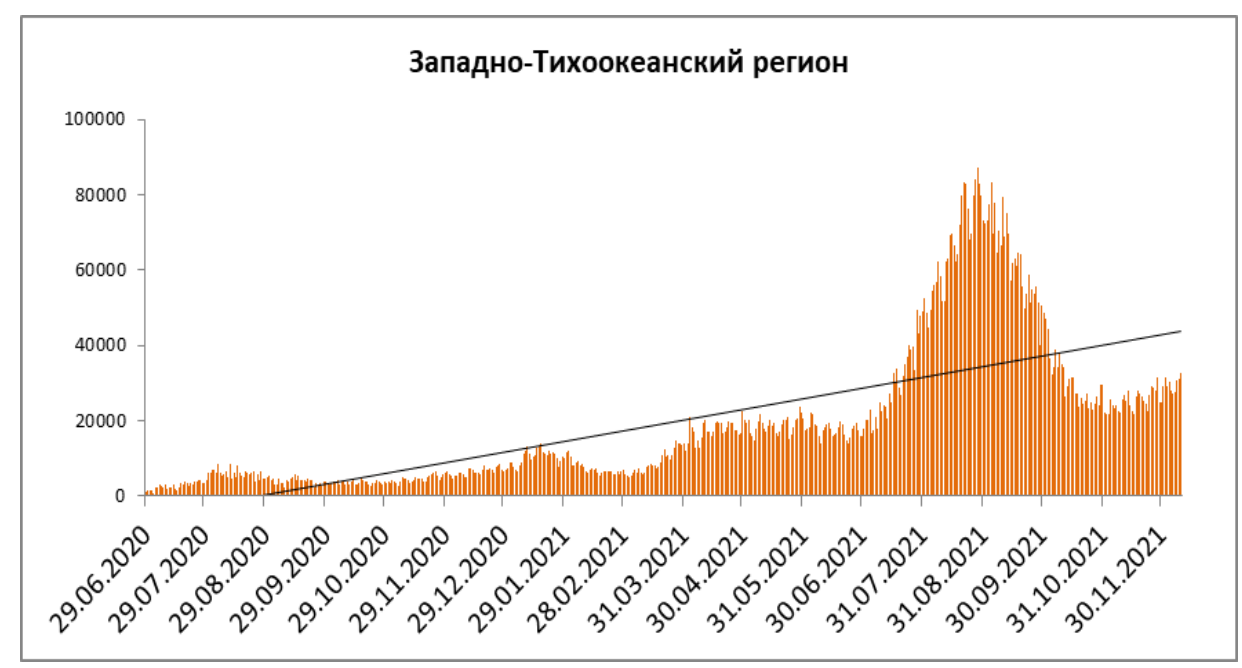

Рисунок 12 - Динамика ежедневного прироста новых случаев в Западно-Тихоокеанском регионе

В 5 странах региона зафиксирован рост числа новых случаев за неделю, наибольший - в Южной Корее и Китае (таб. 5).

Таблица 5 - Страны с максимальным увеличением количества случаев, зарегистрированных за неделю (при сравнении недели с 27 ноября по 3 декабря и недели с 4 по 10 декабря)

\begin{tabular}{|c|c|c|c|c|c|}
\hline \multirow{3}{*}{ Страна } & \multicolumn{4}{|c|}{ Зарегистрировано } & \multirow{3}{*}{ 窟兽蛋 } \\
\hline & \multicolumn{2}{|c|}{ с 27 ноября по 3 декабря } & \multicolumn{2}{|c|}{ с 4 по 10 декабря } & \\
\hline & абс. число & на 1 млн & абс. число & на 1 млн & \\
\hline Южная Корея & 29654 & 573 & 41051 & 793 & $38,4 \%$ \\
\hline Китай & 510 & 0,45 & 635 & 1 & $24,5 \%$ \\
\hline
\end{tabular}

На Малайзию и Вьетнам приходится $65,2 \%$ от всех выявленных случаев за неделю в Западно-Тихоокеанском регионе (рис. 13). 


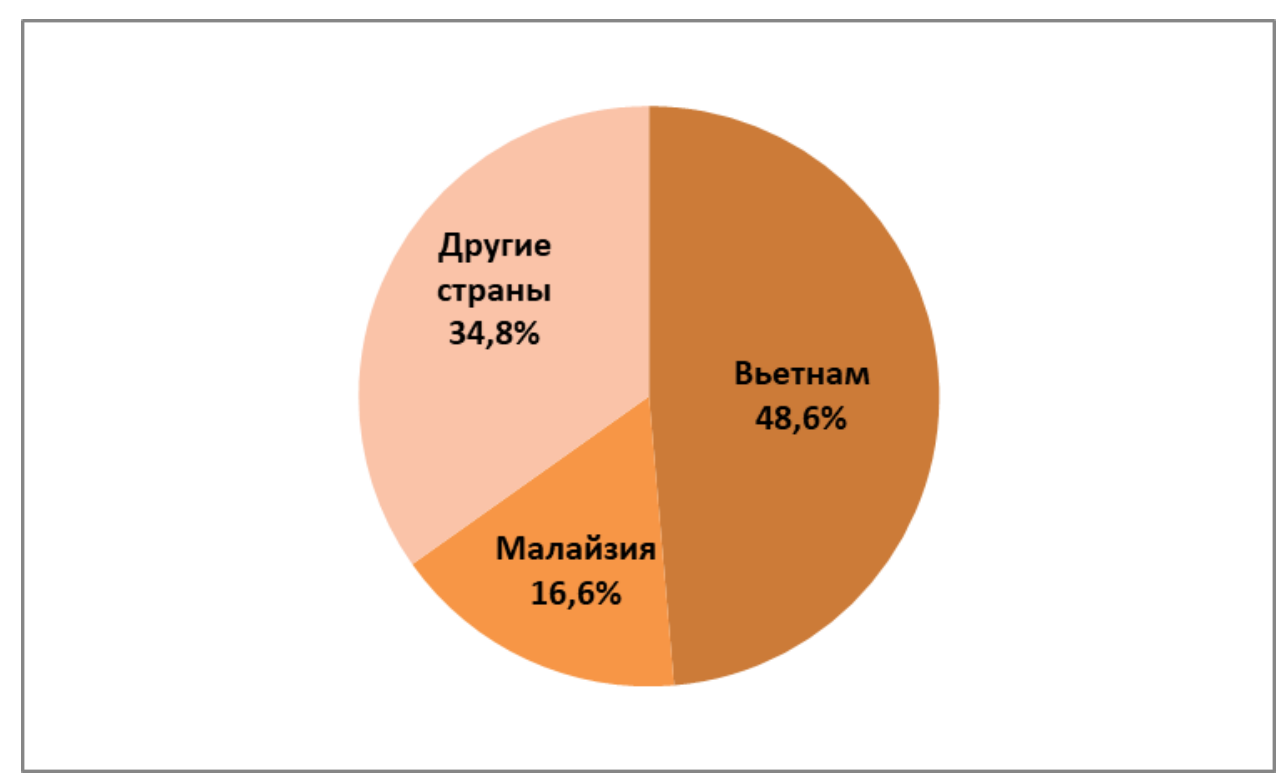

Рисунок 13 - Доля Вьетнама, Малайзии и других стран в количестве случаев, зарегистрированных за отчетную неделю.

В регионе наибольшее число новых случаев заражения на 1 млн населения за неделю зарегистрировано в Лаосе (1124) и Вьетнаме (1051). Наибольшее число летальных исходов на 1 млн населения зафиксировано во Вьетнаме (16) и на Филиппинах (10).

В настоящее время продолжает ухудшаться эпидситуация с COVID-19 в Южной Корее (рис. 14). Центр по контролю и профилактике заболеваний Южной Кореи отмечает, что в стране третьи сутки подряд выявляют свыше 7 тыс. инфицированных ежедневно, что является рекордным показателем с начала пандемии. Также рекордные показатели наблюдаются и среди числа пациентов, находящихся в критическом состоянии. Как минимум до 2 января максимальное количество участников частных встреч сокращено до 6 в столичном регионе и до 8 в других районах. Система COVID-пропусков, которая ранее применялась к отдельным объектам с высоким риском заражения, таким как крытые тренажерные залы, бары и ночные клубы, теперь распространена на большин- 
ство общественных мест, включая рестораны, кафе, караоке, сауны, концертные залы, музеи, библиотеки и учебные заведения.

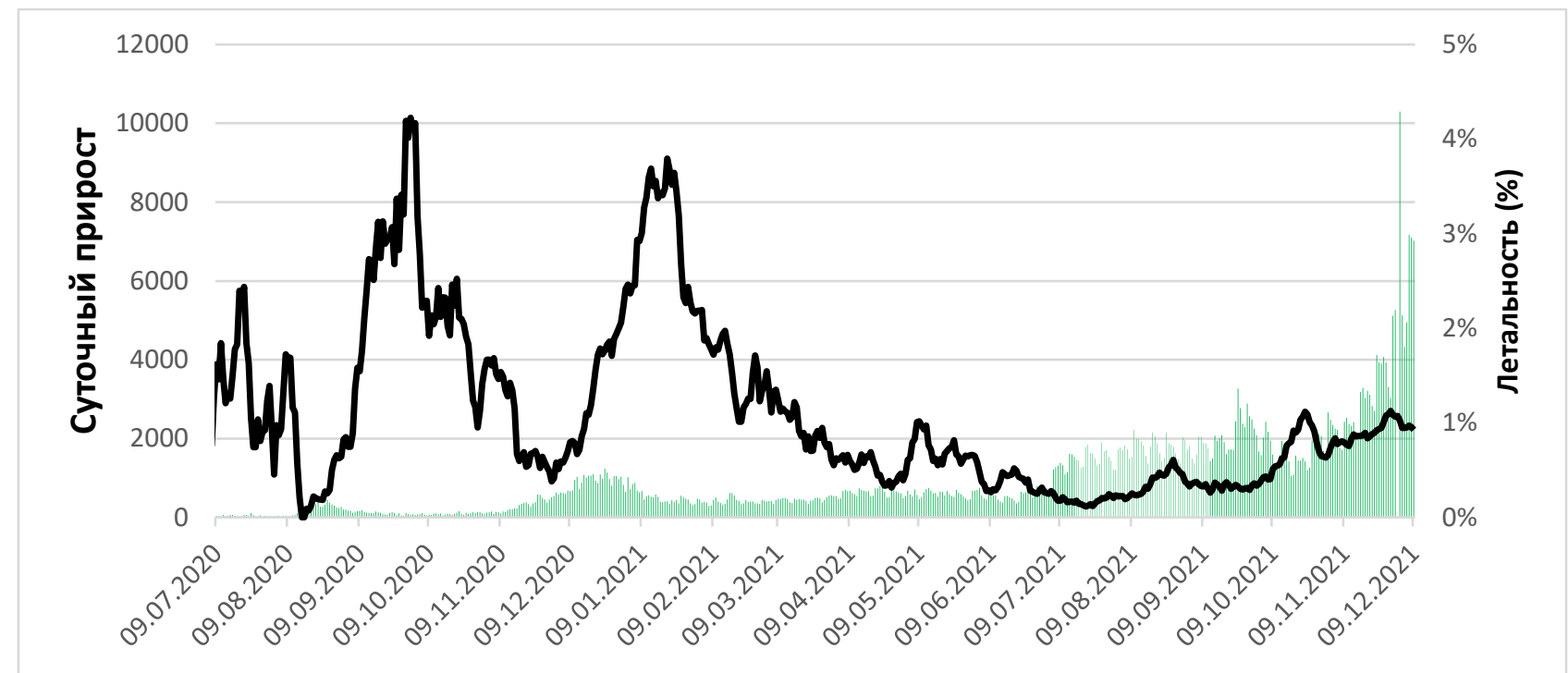

Рисунок 14 - Динамика ежесуточного прироста новых случаев и летальности в Южной Корее (как отношения средних показателей прироста смертей и случаев за 7-дневный период)

\section{Восточно-Средиземноморский регион}

В регионе на анализируемой неделе наблюдается снижение числа новых случаев заболевания на $3,7 \%$ в сравнении с прошлой неделей (рис. 15).

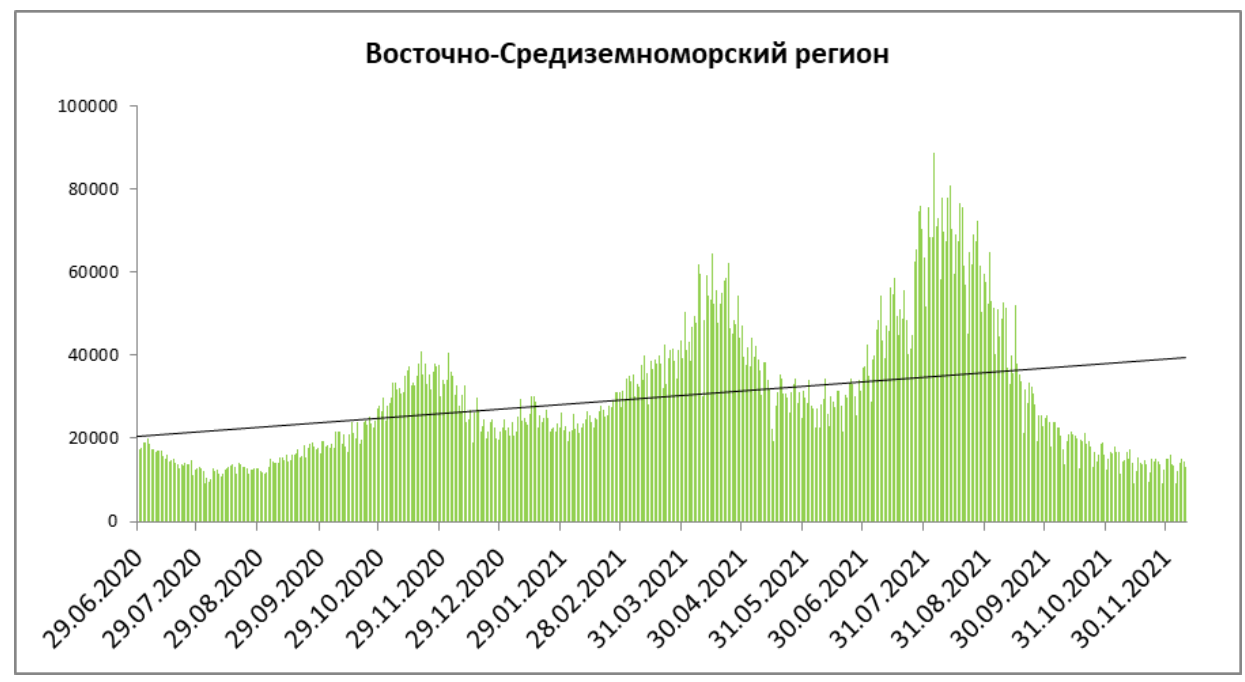


Рисунок 15 - Динамика ежедневного прироста новых случаев в ВосточноСредиземноморском регионе

За неделю с 4 по 10 декабря в 10 из 22 стран региона отмечен рост числа новых случаев. Максимальное увеличение недельного прироста зафиксировано в Саудовской Аравии и ОАЭ (таб. 7).

Таблица 6 - Страны с максимальным увеличением количества случаев, зарегистрированных за неделю (при сравнении недели с 27 ноября по 3 декабря и недели с 4 по 10 декабря)

\begin{tabular}{|c|c|c|c|c|c|}
\hline \multirow{3}{*}{ Страна } & \multicolumn{4}{|c|}{ Зарегистрировано } & \multirow{3}{*}{ 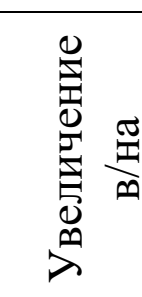 } \\
\hline & \multicolumn{2}{|c|}{ с 27 ноября по 3 декабря } & \multicolumn{2}{|c|}{ с 4 по 10 декабря } & \\
\hline & абс. число & на 1 млн & абс. число & на 1 млн & \\
\hline $\begin{array}{c}\text { Саудовская } \\
\text { Аравия }\end{array}$ & 192 & 5,6 & 278 & 8 & $44,8 \%$ \\
\hline ОАЭ & 389 & 39,8 & 458 & 47 & $17,7 \%$ \\
\hline
\end{tabular}

На Иран и Иорданию приходится $64,7 \%$ от всех выявленных случаев за неделю с 4 по 10 декабря в Восточно-Средиземноморском регионе (рис. 16).

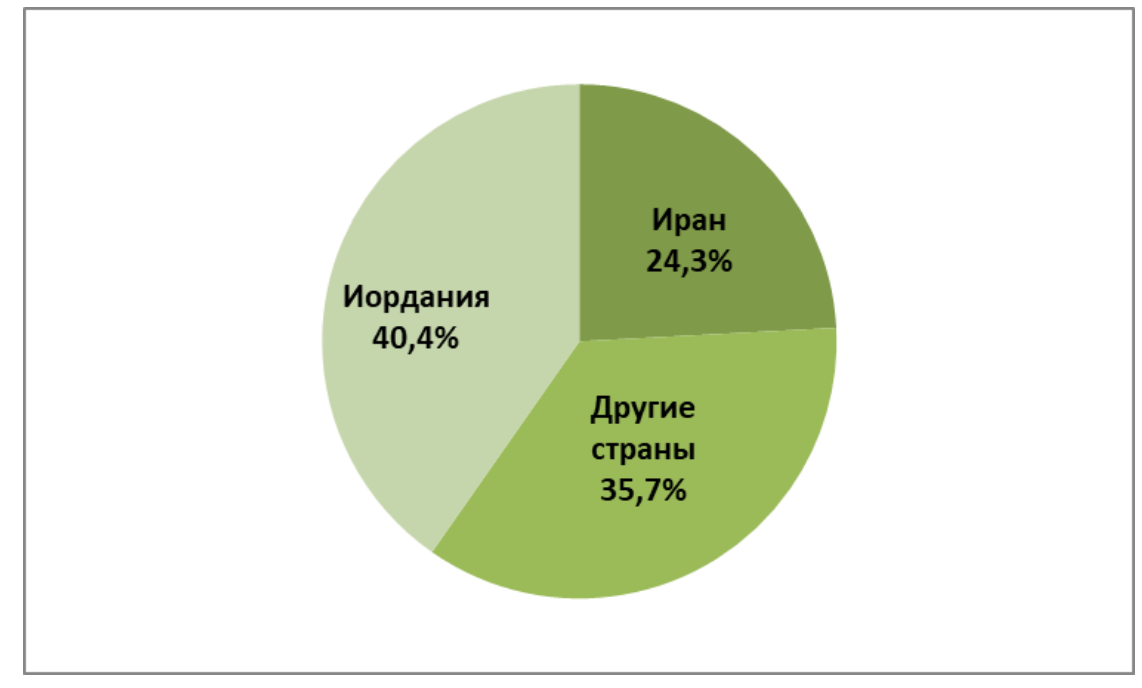

Рисунок 16 - Удельный вес Ирана, Иордании и других стран в структуре случаев в Восточно-Средиземноморском регионе 
Наибольшее число заболевших на 1 млн населения за последнюю неделю зарегистрировано в Иордании (3242) и Ливане (1628). Наибольшее число летальных исходов на 1 млн населения за последнюю неделю зарегистрировано в Иордании (20) и Ливане (10).

В Иордании в настоящее время наблюдается неблагоприятная эпидситуация с COVID-19 (рис.17). В стране продолжается третья волна эпидемии. Национальный центр безопасности и управления кризисными ситуациями королевства с 12 декабря вводит дополнительные ограничительные меры в связи с обнаружением омикрон-штамма в стране. Так, все въезжающие из-за границы должны будут сдать ПЦР-тест за 72 часа до прибытия, зарегистрироваться на специальной платформе и получить QR-код. Также необходимо сдать повторный ПЦР-тест по прибытии в королевство. Данное решение не распространяется на детей в возрасте до 5 лет.

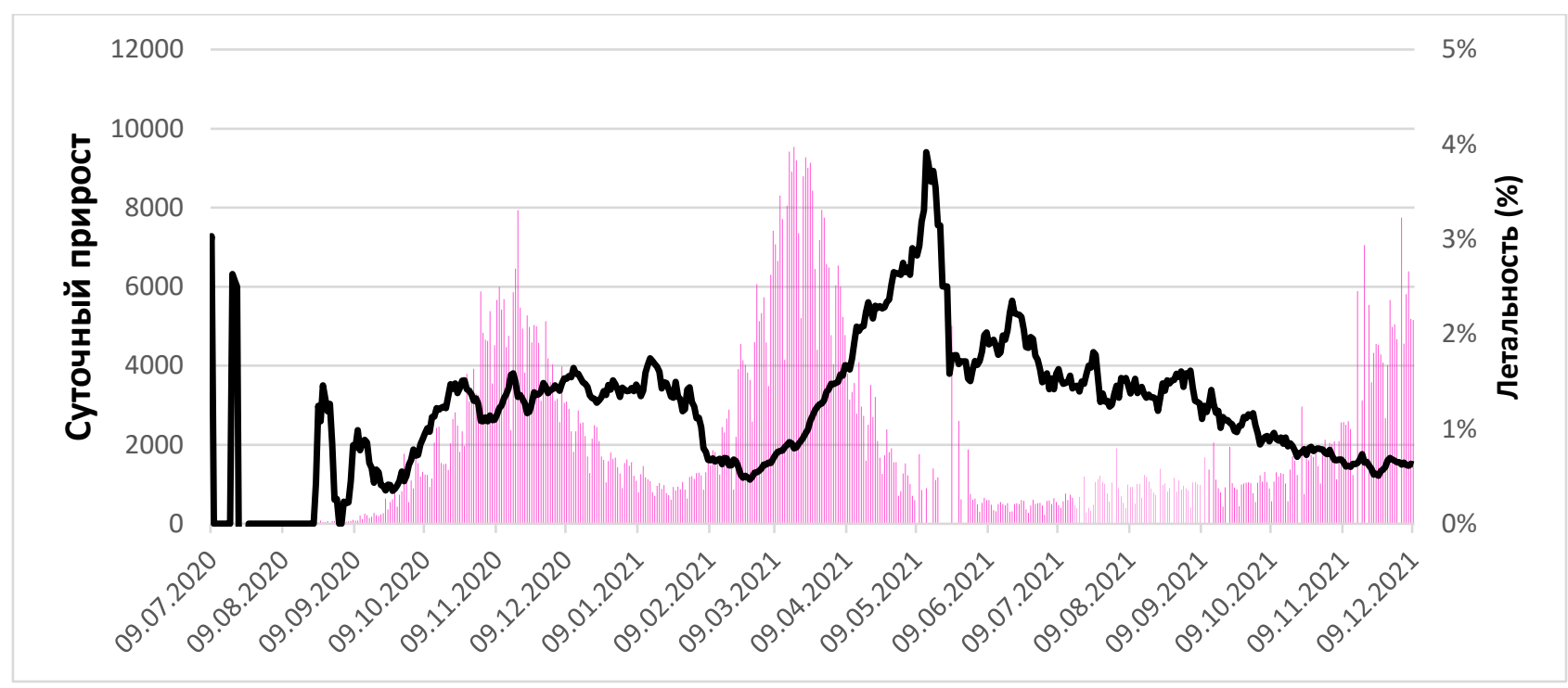

Рисунок 17 - Динамика ежесуточного прироста новых случаев заболевания и летальности в Иордании (как отношения средних показателей прироста смертей и случаев за 7-дневный период). 


\section{Юго-Восточная Азия}

В регионе на анализируемой неделе наблюдается снижение числа новых случаев на $8,1 \%$ в сравнении с прошлой неделей (рис.18).

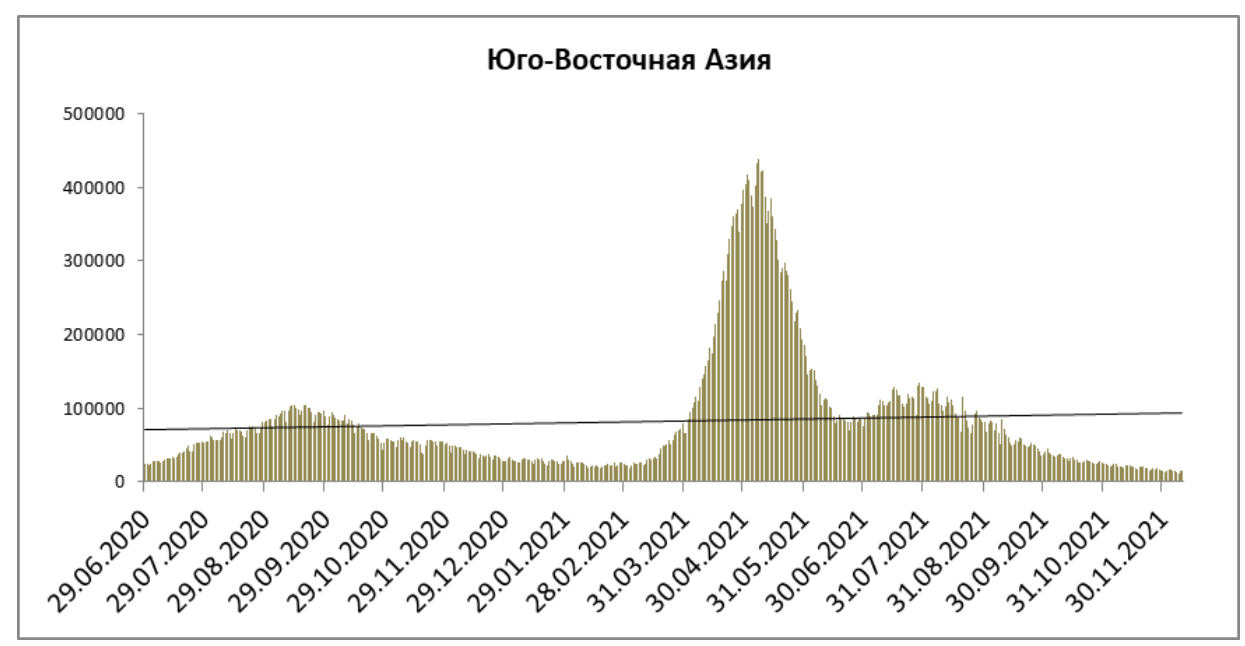

Рисунок 18 - Динамика ежедневного прироста новых случаев в Юго-Восточной Азии

Рост заболеваемости за последнюю неделю отмечен в 5 странах региона, наибольший - на Мальдивах.

Таблица 7 - Страны с максимальным увеличением количества случаев, зарегистрированных за неделю (при сравнении недели с 27 ноября по 3 декабря и недели с 4 по 10 декабря)

\begin{tabular}{|c|c|c|c|c|c|}
\hline \multirow{2}{*}{ Страна } & \multicolumn{4}{|c|}{ Зарегистрировано } & \multirow{2}{*}{} \\
\cline { 2 - 5 } & $\mathrm{c} 27$ ноября по 3 декабря & \multicolumn{2}{|c|}{ с 4 по 10 декабря } & \\
\cline { 2 - 6 } & абс. число & на 1 млн & абс. число & на 1 млн & $11,7 \%$ \\
\hline Мальдивы & 771 & 1402 & 861 & 1566 & 1 \\
\hline
\end{tabular}


На Таиланд и Индию приходится 87,3\% от всех выявленных за неделю случаев в Юго-Восточной Азии в период с 4 по 10 декабря (рис.19).

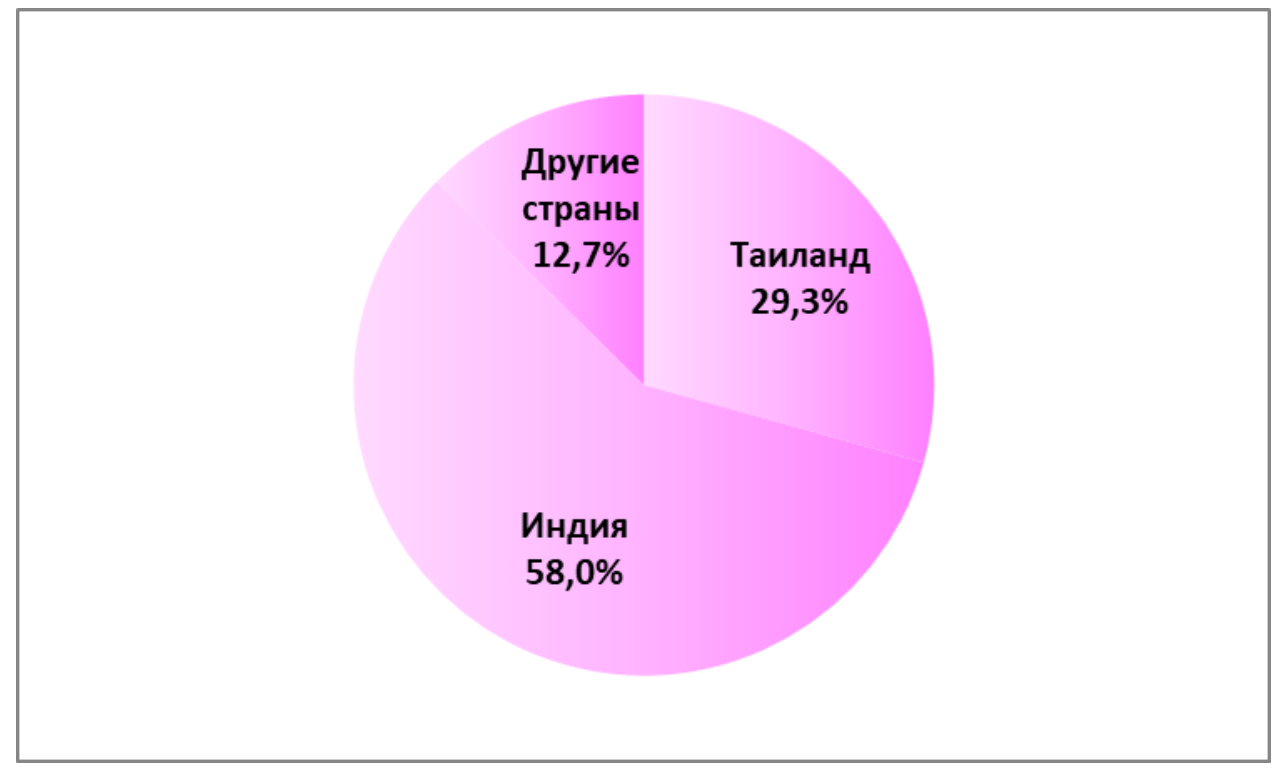

Рисунок 19 - Доля Индии, Таиланда и других стран региона в количестве случаев, зарегистрированных за отчетную неделю

Наибольшее число заболевших на 1 млн населения за последнюю неделю зарегистрировано на Мальдивах (1566) и в Таиланде (453). Наибольшее число летальных исходов на 1 млн населения за последнюю неделю в регионе зарегистрировано на Шри-Ланке (7) и Мальдивах (7).

В настоящее время наблюдается стабильный уровень заболеваемости COVID-19 в Индии (рис. 20). Однако, уровень летальности в стране увеличился до 339 случаев на 1 млн населения. Главное управление гражданской авиации Индии продлило запрет на международные пассажирские полеты до конца января 2022 года. Отмечается, что ограничение не распространяется на одобренные управлением международные рейсы и грузовые самолеты. Ранее власти Индия из-за омикрон-штамма пересмотрели решение об открытии страны для международных рейсов с 15 декабря. 


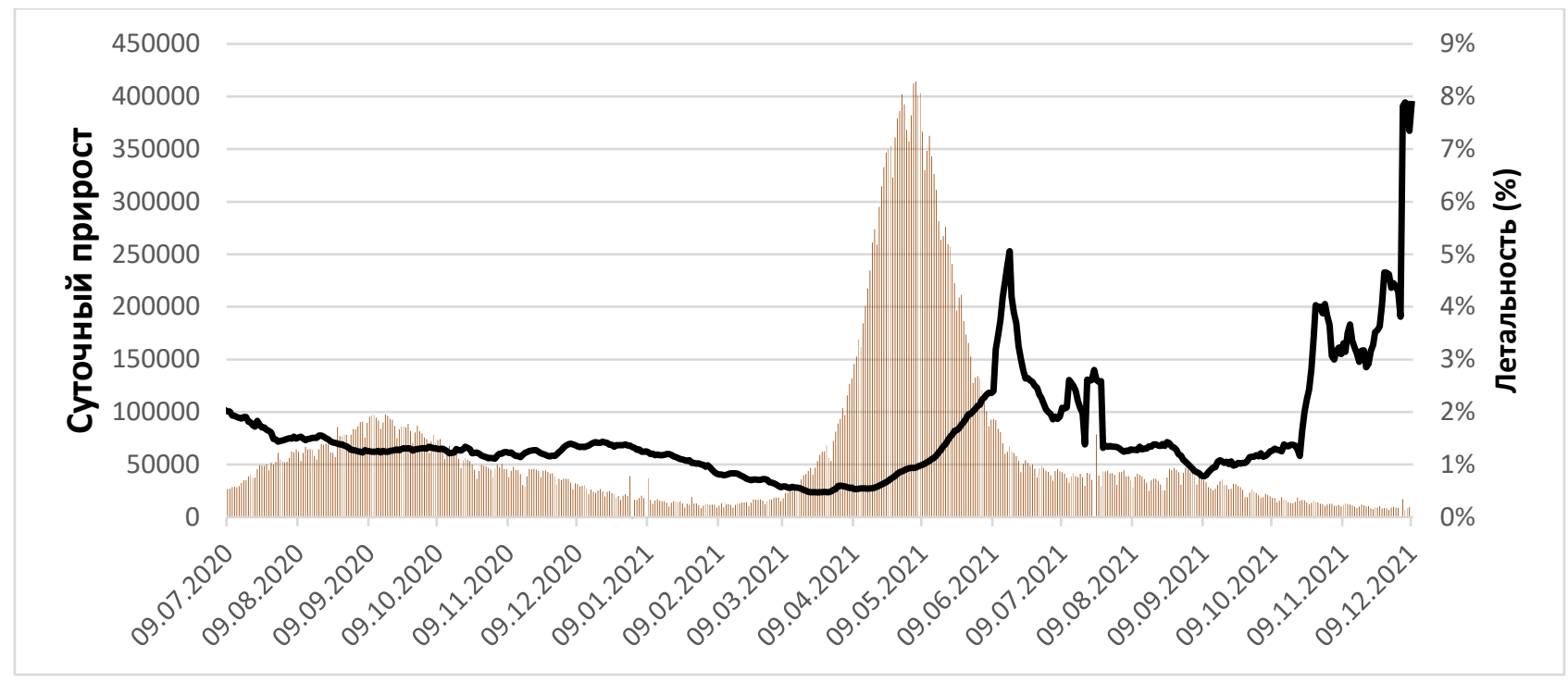

Рисунок 20 - Динамика ежесуточного прироста новых случаев заболевания и летальности в Индии (как отношения средних показателей прироста смертей и случаев за 7-дневный период)

\section{Африканский регион}

В регионе на анализируемой неделе наблюдается рост числа новых случаев заболевания на 85,2\% в сравнении с прошлой неделей (рис. 21).

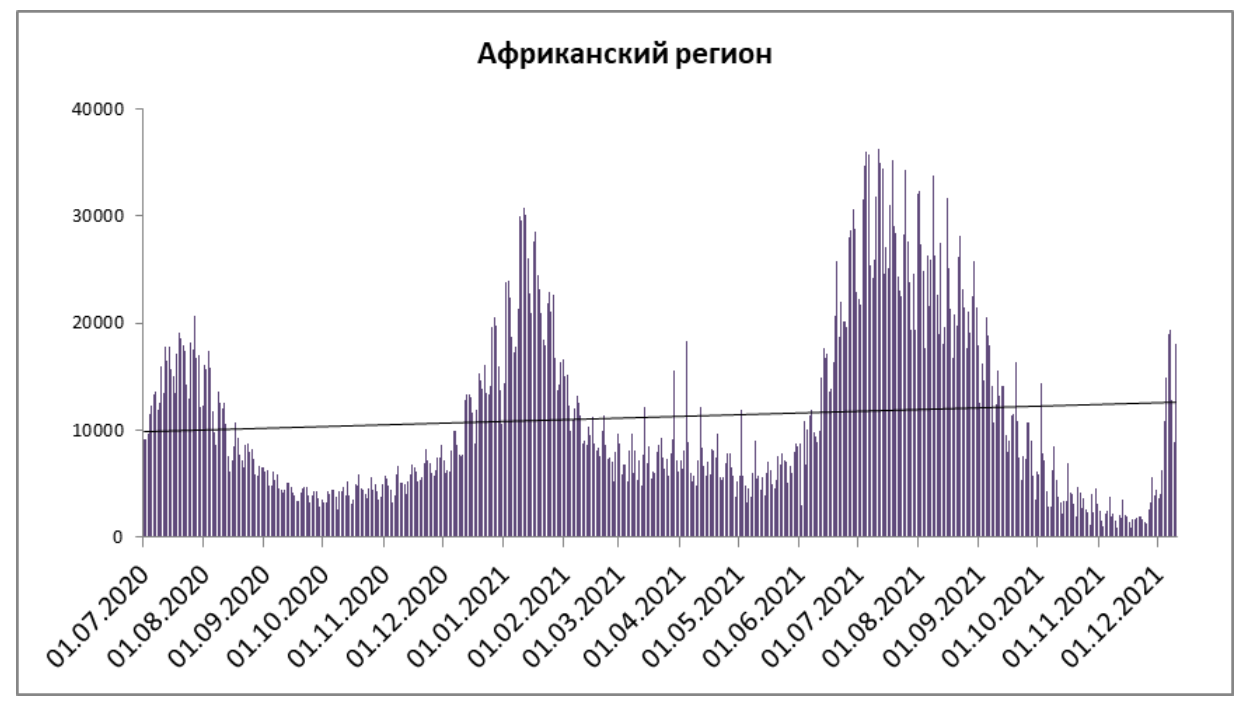

Рисунок 21 - Динамика ежедневного прироста новых случаев в Африканском регионе 
В 30 из 48 стран Африканского региона зарегистрирован рост числа новых случаев. Максимальное увеличение еженедельного прироста новых случаев по сравнению с предшествующей неделей демонстрируют Намибия, Эсватини, Зимбабве и Мозамбик (таб. 9).

Таблица 8 - Страны с максимальным увеличением количества случаев, зарегистрированных за неделю (при сравнении недели с 27 ноября по 3 декабря и недели с 4 по 10 декабря).

\begin{tabular}{|c|c|c|c|c|c|}
\hline \multirow{2}{*}{ Страна } & \multicolumn{4}{|c|}{ Зарегистрировано } & \multirow{2}{*}{$\begin{array}{c}\text { Увеличе- } \\
\text { ние в/на }\end{array}$} \\
\cline { 1 - 5 } & с 27 ноября по 3 декабря & с 4 по 10 декабря & \\
\cline { 1 - 5 } & абс. число & на 1 млн & абс. число & на 1 млн & \\
\hline Намибия & 110 & 44,1 & 987 & 396 & в 9 раз \\
\hline Эсватини & 403 & 351 & 3420 & 2979 & в 8,5 ра3 \\
\hline Зимбабве & 2605 & 178 & 19438 & 1327 & в 7,5 раз \\
\hline Мозамбик & 140 & 4,6 & 934 & 31 & в 6,7 раз \\
\hline
\end{tabular}

На ЮАР приходится 74,6\% от всех выявленных за неделю случаев в Африканском регионе в период с 4 по 10 декабря (рис. 22).

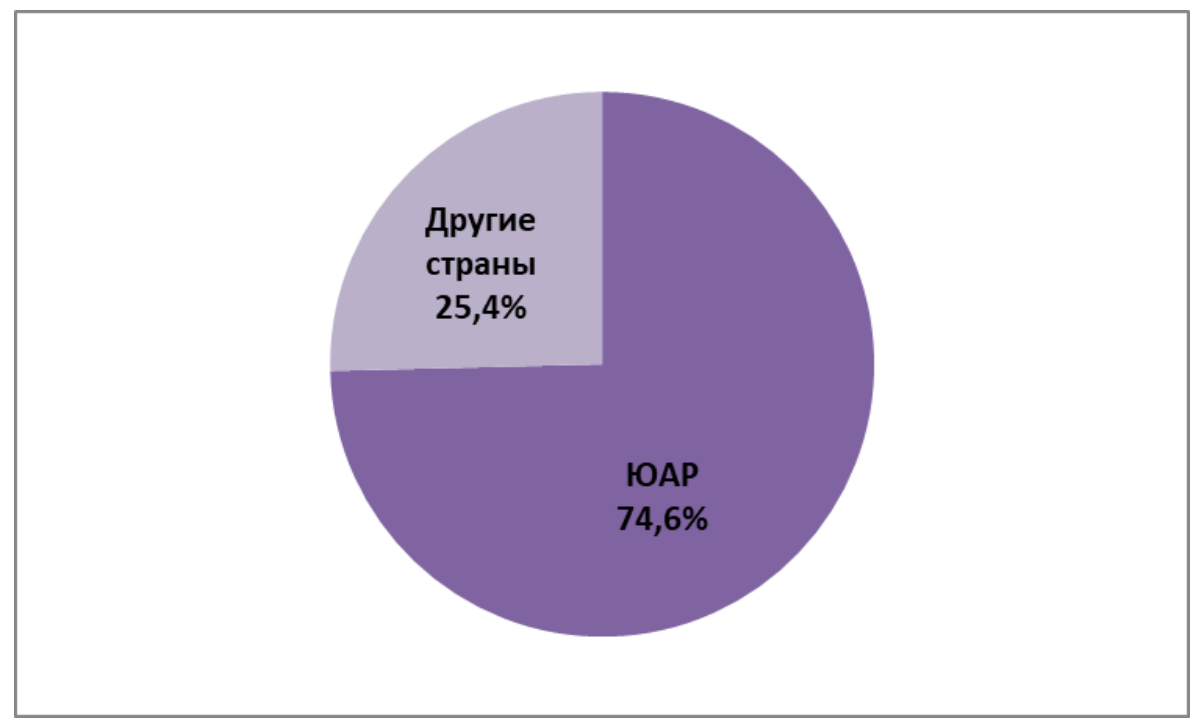

Рисунок 22 - Удельный вес ЮАР и других стран в структуре случаев, зарегистрированных за отчетную неделю в Африканском регионе 
Наибольшее число заболевших на 1 млн населения за последнюю неделю зарегистрировано в Эсватини (2979) и на Сейшелах (2745). Наибольшее число летальных исходов на 1 млн населения за последнюю неделю зарегистрировано на Сейшелах (20) и в Сан-Томе и Принсипи (5).

Ухудшение эпидситуации с COVID-19 в настоящее время продолжается в ЮАР (рис.23). В течение первой недели декабря в ЮАР основной группой по количеству новых случаев заражения стали дети в возрасте от 10 до 14 лет, сообщил Национальный институт инфекционных заболеваний (НИИЗ) ЮАР. Отмечается, что подавляющее большинство заболевших (70\%) в ЮАР инфицированы омикрон-штаммом. Врачи подчеркивают, что у молодых людей заболевание, вызванное этим штаммом, протекает в легкой форме и не требует госпитализации. Наибольшее число заболевших зарегистрировано в столичной провинции Гаутенг.

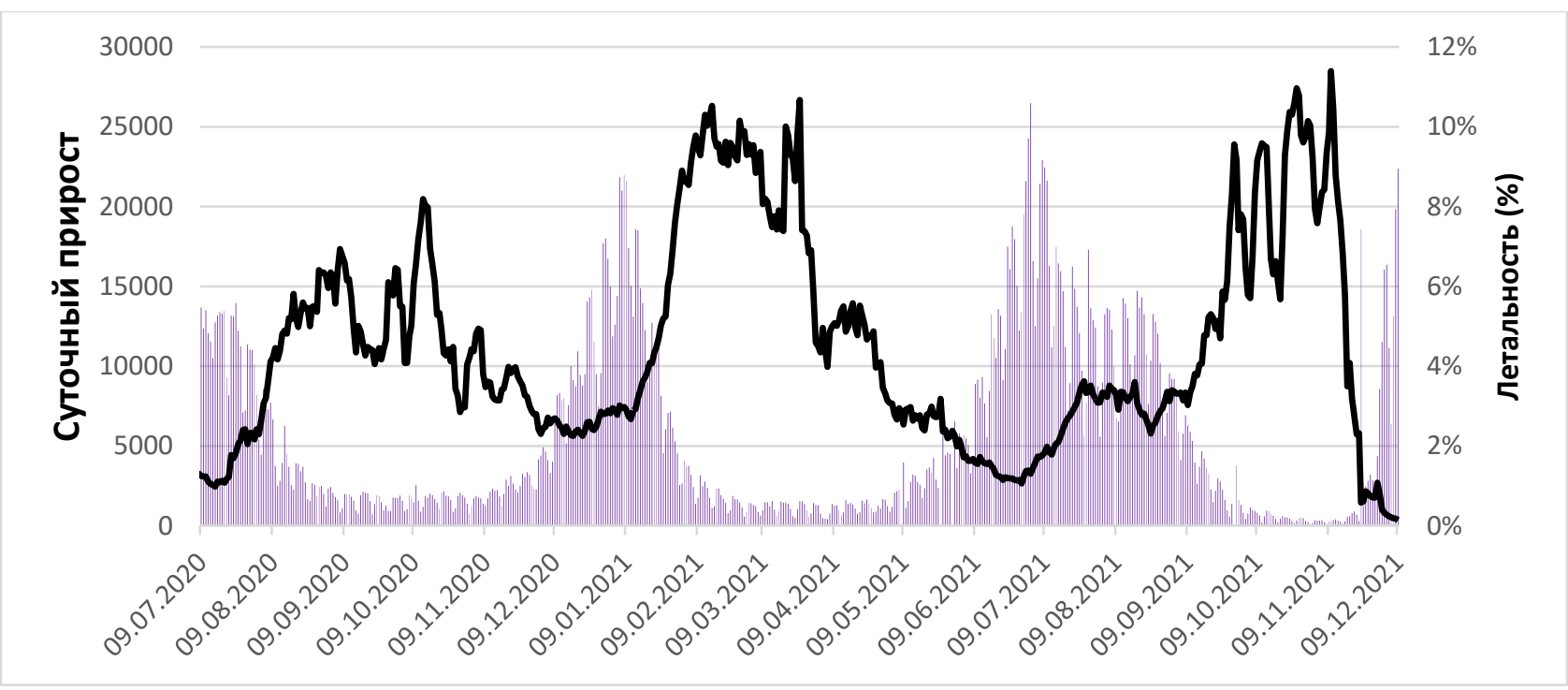

Рисунок 23 - Динамика ежесуточного прироста новых случаев заболевания и летальности в ЮАР (как отношения средних показателей прироста смертей и случаев за 7-дневный период) 